\title{
MENINGKATKAN KEMANDIRIAN BELAJAR MELALUI LAYANAN PENGUASAAN KONTEN DENGAN TEKNIK MODELING SIMBOLIK DI SMP NEGERI 1 SUNGAI KAKAP
}

\author{
Amelia Atika ${ }^{1}$, M. K Aziz ${ }^{2}$ \\ ${ }^{1}$ Program Studi Bimbingan dan Konseling \\ Fakultas Ilmu Pendidikan dan Pengetahuan Sosial IKIP PGRI Pontianak \\ Jalan Ampera Nomor 88 Pontianak-78116, Telepon (0561) 748219 Fax. (0561) 6589855 \\ ${ }^{2}$ SMP Negeri 1 Sungai Kakap \\ Jalan Raya Sungai Kakap, Kubu Raya-78381, Telp. (0561) 575449 \\ ${ }^{1}$ Alamat e-mail: ameliatika200799@gmail.com
}

\begin{abstract}
Abstrak
Penelitian ini secara umum bertujuan untuk meningkatkan kemandirian belajar melalui layanan penguasaan konten dengan teknik modeling simbolik pada siswa kelas VIII B SMP Negeri 1 Sungai Kakap. Metode yang digunakan dalam penelitian ini adalah metode deskriptif dan bentuk penelitiannya Penelitian Tindakan Bimbingan dan Konseling (PTBK) dengan pendekatan kuantitatif dan kualitatif, yaitu untuk mendeskripsikan dan melihat kenyataan di lapangan sebagaimana kenyataan yang ada dan sebagai mana adanya mengenai kemandirian belajar melalui layanan penguasaan konten dengan teknik modeling simbolic pada siswa kelas VIII B SMP Negeri 1 Sungai Kakap. Berdasarkan dari hasil penelitian tindakan yang telah dilaksanakan oleh peneliti, maka dapat diambil kesimpulan bahwa terdapat peningkatan kemandirian belajar melalui layanan penguasaan konten dengan teknik modeling simbolic pada siswa kelas VIII B SMP Negeri 1 Sungai Kakap.
\end{abstract}

Kata Kunci: Kemandirian Belajar, Layanan Penguasaan Konten, Teknik Modeling Simbolik

\begin{abstract}
This research generally aims to increase learning independence through group guidance services with modeling techniques in class VIII B SMP Negeri 1 Sungai Kakap. Methods used in this research was descriptive methods with guidance and counseling action research form with quantitative and qualitative approaches, namely describe and see the reality on the ground as well as the fact that there are about learning independence through group counseling service with modeling techniques for class VIII B SMP Negeri 1 Sungai Kakap students. Based on the results of action research which has been carried on by researchers, it can be concluded that there is an increase in learning independence through group guidance service to the modeling techniques in class VIII B SMP Negeri 1 Sungai Kakap.
\end{abstract}

Keywords: learning Independence, content mastery service, simbolic modeling techniques

\section{PENDAHULUAN}

Dampak globalisasi yang terjadi saat ini membawa masyarakat Indonesia melupakan pendidikan karakter. Padahal pendidikan karakter merupakan suatu pondisi bangsa yang sangat penting dan perlu ditanamkan sejak dini kepada anak- 
anak. Karakter merupakan aspek yang penting untuk kesuksesan individu dimasa depan merupakan titian ilmu pengetahuan dan keterampilan. Karakter bukan sekedar penampilan lahiriah, melainkan mengungkapkan secara implisit hal-hal yang tersembunyi. Kemendiknas $(2010 ; 15)$ "Pendidikan karakter merupakan upaya-upaya yang dirancang dan dilaksakan secara sistematis untuk menanamkan nilai-nilai perilaku peserta didik yang berhubungan dengan Tuhan Yang Maha Esa, diri sendiri, sesama manusia, lingkungan dan kebangsaan, yang terwujud dalam pikiran, sikap, perasaan, perkataan, dan perbuatan berdasarkan normanorma agama, hukum dan tata krama, budaya, dan adat istiadat."

Dalam pendidikan karakter terdapat nilai-nilai karakter yang dikembangkan. Khususnya untuk Sekolah Menengah Pertama, terdapat 20 nilai utama yang dikembangkan dan disarikan dari butir-butir SKL SMP. Adapun 20 nilai karakter tersebut menurut Kemendiknas (2010:15-19) adalah nilai religius; jujur; bertanggung jawab; bergaya hidup sehat; disiplin; kerja keras; percaya diri; berjiwa wirausaha; berfikir logis; kritis; kreatif dan inovatif; mandiri; ingin tahu; cinta ilmu; sadar akan hak dan kewajiban diri orang lain; santun; demokratis; ekologis; nasionalis; menghargai keberagaman.

Sejalan dengan pendapat yang dikemukakan oleh Prayitno (2004:114) bahwa: "tujuan bimbingan dan konseling adalah membantu individu untuk menjadi insan yang mandiri yang memiliki kemampuan untuk memahami diri sendiri dan lingkungannya secara tepat dan objektif, menerima diri sendiri dan lingkungan secara positif dan dinamis, mampu mengambil keputusan secara tepat dan bijaksana, mengarahkan diri sendiri sesuai dengan keputusan yang diambil, serta akhirnya mampu mewujudkan diri sendiri secara optimal”.

Tujuan bimbingan dan konseling tersebut tertuang dalam standar kompetensi kemandirian peserta didik yang di dalamnya terdapat berbagai macam aspek perkembangan (Depdiknas, 2007: 253-258). Hal ini merupakan salah satu yang dikembangkan dalam pendidikan karakter yaitu nilai kemandirian. Nilai kemandirian sangat penting ditumbuhkan di dalam diri siswa karena akan menjunjung perkembangan potensi optimal yang dimiliki oleh siswa. 
Mandiri merupakan suatu suasana dimana seseorang mau dan mampu mewujudkan kehendak dirinya yang terlihat dalam perbuatan nyata guna menghasilkan sesuatu demi pemenuhan kebutuhan hidupnya dan sesamanya. Kenyataan di lapangan berdasarkan informasi dari guru BK di SMP Negeri 1 Sungai Kakap, siswa belum sepenuhnya memiliki nilai kemandirian terutama dalam hal belajar. Khususnya siswa kelas VIII B. Hal ini dapat dilihat dari permasalahan yang nampak di kelas VIIIB, diantaranya adalah siswa tidak yakin pada diri kemampuan diri sendiri sendiri, minta diarahkan guru secara terus menerus dalam kegiatan belajar, siswa membutuhkan dukungan dari orang lain yang berlebihan, tidak mampu belajar mandiri, melaksakan kegiatan berdasarkan perintah orang lain, sering menyontek pekerjaan teman, tidak memiliki tanggung jawab di dalam belajar, dan siswa ingin cepat-cepat mengakhiri kegiatan belajarnya. Permasalahan tersebut mengambarkan bahwa nilai kemandirian belajar dalam diri siswa belum tampak. Apabila keadaan seperti ini tidak segera ditangani, dikhawatirkan akan berpengaruh terhadap prestasi belajar siswa di sekolah.

Layanan penguasaan konten diasumsikan tepat dalam membantu meningkatkan kemandirian belajar siswa. Layanan penguasaan konten adalah salah satu jenis layanan bimbingan dan konseling yang memungkinkan siswa dapat memahami dan mengembangkan sikap dan kebiasaan belajar yang baik, keterampilan dan materi belajar yang cocok dengan kecepatan dan kesulitan belajarnya, serta tuntunan kemampuan yang berguna dalam kehidupan dan perkembangan dirinya. Layanan penguasaan konten dipilih sebagai tindakan sebagai media dalam upaya membimbing individu yang bertujuan untuk mengembangkan konten karakter kemandirian. Melalui layanan penguasaan konten siswa mendapat berbagai informasi tentang sikap mandiri yang berbedabeda. Demikian pula dipilihnya teknik modeling simbolik diharapkan siswa dapat dengan mudah memahami bentuk karakter mandiri melalui belajar mengobservasi/mengamati model yang ditayangkan melalui film atau video. Dengan kata lain siswa dapat mengembangkan kemandirian belajar dengan melihat fenomena yang ada. 


\section{METODE}

Penelitian ini menggunakan metode penelitian deskriptif, yaitu melihat kenyataan di lapangan sebagaimana kenyataan yang ada dan sebagai mana adanya ( Suryabrata 2010:37). Alasan menggunakan metode deskriptif adalah karena peneliti ingin memperoleh gambaran tentang pelaksanaan tindakan Layanan Penguasaan Konten dengan teknik modeling simbolik untuk meningkatkan kemandirian belajar siswa.

Bentuk penelitian yang digunakan adalah penelitian tindakan kelas bimbingan dan konseling (PTK-BK). Tadjri (2012; 7) PTK BK merupakan suatu bentuk penelitian yang bersifat reflektif dengan melakukan tindakan-tindakan tertentu agar dapat memperbaiki dan atau meningkatkan praktek pelayanan konseling agar lebih profesional . PTKBK merupakan penelitian kolaboratif, yaitu penelitian kerja sama antara konselor dan teman sejawat dimana mereka bekerja.

Sejalan pendapat di atas, PTKBK yang dimaksud dalam penelitian ini adalah peneliti dan kolaborator bersama-sama melakukan tindakan berupa layanan penguasaan konten dengan teknik modeling simbolik. Adapun langkah-langkah dalam penelitian ini adalah:

1. Perencanaan

a. Peneliti menentukan analisa kebutuhan sasaran yang akan diberikan layanan penguasaan konten dengan teknik modeling simbolik

b. Membuat rencana pelaksanaan layanan (RPL)

c. Menentukan teknik pemecahan masalah

d. Membuat instrumen penilaian segera

e. Menyusun alat evaluasi pelaksanaan layanan penguasaan konten

2. Tindakan

Pelaksanaan layanan penguasaan konten akan diadakan berdasarkan indikator kinerja capaian, setiap siklus diadakan 3 kali pertemuan. Dengan layanan ini siswa tidak hanya memahami topik layanan, akan tetapi mereka juga dapat mengobservasi/ mengamati dan menginterpretasikan untuk setiap 
materi yang disampaikan dan video/film yang ditaynagkan (teknik modeling simbolik)

\section{Observasi}

a. Observasi terhadap peneliti dalam pelaksanaan layanan penguasaan konten dengan teknik modeling simbolik

b. Observasi terhadap siswa dalam perkembangan peningkatan kemandirian belajar.

4. Refleksi

a. Evaluasi bersama kolaborator

b. Perbaikan siklus berikutnya atau stop pemberian tindakan

Dalam penelitian ini yang menjadi subyek penelitian adalah siswa kelas VIII B Sekolah Menengah Pertama Negeri 1 Sungai Kakap Kabupaten Pontianak, dengan jumlah siswa yang diteliti sebanyak 43 siswa yang terdiri atas 15 siswa laki-laki dan 28 siswa perempuan, hal ini juga berdasarkan informasi yang diberikan oleh guru bimbingan dan konseling serta diperkuat oleh wali kelas VIII B saat peneliti melakukan prasurvei bahwa ada beberapa siswa yang kemandirian belajarnya masih rendah di Sekolah Menengah Pertama Negeri 1 Sungai kakap Kabupaten Pontianak. Dengan karakteristik masalah sebagai berikut: (1) siswa tidak yakin pada kemampuan diri sendiri, (2) siswa minta diarahkan guru secara terus menerus, (3) tidak mampu belajar mandiri, (4) siswa belajar sesuai perintah, (5) siswa sering mencontek, (6) siswa yang tidak memiliki motivasi dalam belajar..

Teknik pengumpulan data yang digunakan dalam penelitian adalah teknik komunikasi langsung dan teknik observasi langsung, dengan alat pengumpul data angket dan pedoman observasi. Angket digunakan untuk mencari data gambaran atau profil kemandirian belajar sebelum dan sesudah penerapan layanan penguasaan konten, sedangkan pedoman observasi digunakan untuk melihat pelaksanaan tindakan layanan penguasaan konten. Teknik analisis data dalam penelitian ini adalah analisis data kuantitatif dan kualitatif. Analisis kuantitatif data angket digunakan perhitungan persentase. 


\section{Tabel 1}

\section{Tolok Ukur Kategori Persentase}

\begin{tabular}{cc}
\hline Persentase $(\%)$ & Kategori \\
\hline $\mathbf{7 5 , 0 1}-\mathbf{1 0 0 , 0 0}$ & Sangat baik \\
$\mathbf{5 0 , 0 1}-\mathbf{7 5 , 0 0}$ & Baik \\
$\mathbf{2 5 , 0 1}-\mathbf{5 0 , 0 0}$ & Cukup \\
$\mathbf{0 0 , 0 0}-\mathbf{2 5 , 0 0}$ & Kurang \\
\hline
\end{tabular}

Sumber: Arikunto (2010: 235)

Data kualitatif yaitu data yang memberikan informasi berbentuk kalimat yang memberikan gambaran tentang tingkat kemandirian belajar siswa sebelum dan sesudah mendapatkan layanan penguasaan konten dengan teknik modelling simbolik. Gambaran kemandirian belajar diperoleh dari data angket yang kemudian ditafsirkan dalm bentuk kategori. Data kualitatif ini juga digunakan untuk menganalisis hasil pengamatan selama proses pelaksanaan layanan penguasaan konten dengan teknik modelling simbolik.

\section{HASIL DAN PEMBAHASAN}

Tujuan yang ingin dicapai dari penelitian ini adalah : (1) Mengetahui kemandirian belajar sebelum diberikan tindakan layanan penguasaan konten, (2) Untuk mengetahui pelaksanaan layanan penguasan konten dengan teknik modelling simbolik, (3) Mengetahui kemandirian belajar siswa setelah diberikan tindakan layanan penguasaan konten dengan teknik modeling simbolik. Pendekatn yang digunakan adalah penelitian tindakan sesuai dengan prosedur, penelitian ini dilakukan dengan berbagai tahap yakni perencanaan, tindakan, observasi dan refleksi keempat rangkaian tersebut dipandang sebagai satu siklus. Dalam pelaksanaan sesungguhnya ada dua siklus yang dilakukan oleh peneliti dimana pada setiap siklus ada tiga kali pertemuan atau tindakan. Untuk meningkatkan kemandirian belajar diungkap melalui data angket sebagai berikut :

1. Tingkat kemandirian belajar siswa sebelum diberikan layanan penguasaan konten dengan teknik modeling simbolik adalah 50,00 \%masuk dalam kategori cukup. 
2. Tingkat kemandirian belajar siswa setelah diberikan layanan penguasaan konten dengan teknik modeling simbolik adalah 68,84\% masuk dalam kategori baik.

Data-data tersebut semakin dikuatkan dengan observasi pelaksanaan layananan penguasaan konten dengan teknik modelling simbolik. Berdasarkan hasil pengamatan pada siklus satu dan dua dapat disimpulkan :

1. Peneliti telah melaksanakan tindakan layanan penguasaan konten dengan teknik modelling simbolik sebanyak delapan kali pertemuan.

2. Teknik yang digunakan oleh peneliti berupa teknik modelling simbolik.

3. Pelaksanaan layanan dilakukan sesuai dengan rencana pelaksanaan layanan (RPL) dan pelaksanaan teknik modelling simbolik telah dilaksanakan sesuai dengan proedur atau tahapanya.

Berdasarkan pada tujuan dan hasil peneitian, maka akan dibahas secara impilif tentang gambaran kemandirian siswa kelas VIII B SMP Negeri 1 Sungai Kakap sebelum diberikan layanan penguasaan konten dengan teknik modelling simbolik, gambaran kemandirian belajar siswa kelas VIII B SMP Negeri 1 Sungai Kakap sesudah diberikan layanan penguasaan konten dan perbedaan kemandirian siswa sebelum dan sesudah layanan penguasaan konten dengan teknik modelling simbolik. Peningkatan dapat terjadi karena adanya faktor stimulus dari dalam dan luar. Dalam hal ini peneliti mencoba mengembangkan kemandirian belajar siswa dengan memberikan stimulus dari luar yaitu dengan pemberian layanan penguasan konten dengan teknik modelling simbolik dalam pelaksanaan dinamika kelompok memiliki peranan penting dengan mengembangkan kemandirian siswa sehingga siswa mengetahui tujuan diadakan layanan tersebut, yakni sebagai upaya untuk meningkatkan kemandirianya.

Kemandirian yang dimiliki oleh seseorang itu berbeda-beda sebagian orang ada yang memiliki karakter mandiri yang tinggi, sedang, dan rendah. Hal ini dapat dipengaruhi dari berbagai faktor yang mempengaruhi tingkatan karakter mandiri seseorang diantaranya dari faktor gen atau keturunan orang tua, pola asuh orang tua kepada anak, sistem kehidupan dimasyarakat, sistem pendidikan di sekolah yang kurang mengajari anak mandiri (Ali dan Asrori, 2005: 118-119) 


\section{SIMPULAN}

Berdasarkan hasil pembahasan penelitian dapat dirumuskan beberapa simpulan sebagai berikut :

1. Sebelum pelaksanaan layanan penguasaan konten dengan teknik modelling simbolik tingkat kemandirian belajar siswa masuk dalam kategori cukup.

2. Layanan penguasaan konten dengan teknik modelling simbolik telah dilaksanakan dengan baik.

3. Setelah pelaksanaan layanan penguasaan konten dengan teknik modelling simbolik tingkat kemandirian belajar siswa masuk dalam kategori sedang.

\section{DAFTAR PUSTAKA}

Arikunto, S. 2017. Prosedur Penelitian Suatu Pendekatan Praktik. Jakarta: Rineka Cipta.

Hidayat, D. R. 2012. Penelitian Tindakan dalam Bimbingan dan Konseling. Jakarta: PT. Indeks.

Nawawi, H. 2017. Metode Penelitian Bidang Sosial. Yogyakarta: Gajahmada University Press.

Saddhono, Kundharu. 2007. Oreng Madure dan Wong Solo: Fenomena Integrasi Linguistik Kulural. Surakarta: Program Beasiswa Unggulan Departemen Pendidikan Nasional dan Sebelas Maret University Press.

Suryabrata, S. 2010. Metodologi Penelitian. Jakarta: Raja Grafindo Persada.

Tadjri, I. 2011. Penelitian Tindakan Bimbingan dan Konseling. Semarang: Unnes Press.

Tindall, J. D. \& Gray, H. D. 1985. Peer Counseling: In-Depth Look At Training Peer Helpers. Muncie: Accelerated Development INC.

Ali, mohammad dan Mohammad Asrori, 2005. Psikologi Remaja dan Perkembangan Peserta Didik, Jakarta: PT Bumi Aksara.

Desmita, 2009. Psikologi Perkembangan Peserta Didik. Bandung: PT Remaja Rosdakarya.

Kemendiknas. 2010. Pendidikan Karakter di Sekolah Menengah Pertama 
Prayitno dan Erman Amti. 2004. Dasar-dasar Bimbingan dan Konseling. Jakarta: Rineka Cipta. 